\title{
PENGARUH MODEL COOPERATIVE SCRIPT TERHADAP HASIL BELAJAR SISWA KELAS IX SMP NEGERI 1 KOTA SORONG
}

\author{
Nika Fetria Trisnawatia , Muhamad Ruslan Layn ${ }^{b}$, Arie Anang Setyoc, Rahmatullah Bin \\ Arsyad $^{d}$, Muhammad Fathurrahman ${ }^{\mathrm{e}}$, Sundarif, Tolhas H. Banjarnahorg. \\ Program Studi Pendidikan Matematika FKIP Uiversitas Muhammadiyah Sorong \\ J1. Pendidikan no. 23, KM 8, Sorong, Papua Barat.

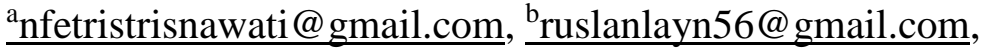 \\ carieanangsetyo.ums@gmail.com, ${ }^{\mathrm{d}}$ rahmatullahbinarsyad@gmail.com, \\ er.fathur19@gmail.com, ${ }^{\mathrm{f}}$ ndarisundari212@gmail.com. \\ gtolhasbanjarnahor398@gmail.com
}

\begin{abstract}
ABSTRAK
Tujuan penelitian ini adalah untuk mengetahui pengaruh dari penerapan model Cooperative Script terhadap hasil belajar. Penelitian ini merupakan penelitian Quasi Experimental Design dengan desain eksperimen Non-Equivalent Pretest-Posttest Design. Populasi penelitian mencakup seluruh siswa kelas IX SMP Negeri 1 Kota Sorong dengan dua kelas sebagai sampel acak, kelas IX A sebagai kelas eksperimen dengan memberikan perlakuan berupa penerapan model Cooperative Script pada pembelajaran dikelas dan kelas IX B sebagai kelas Kontrol dengan tidak memberikan perlakuan khusus. Perangkat yang digunakan untuk pengumpulan data adalah lembar observasi dan soal pretest - post test. Hasil penelitian menunjukkan adanya pengaruh positif yang signifikan dari penerapan model Cooperative Script terhadap hasil belajar kelas IX A SMP Negeri 1 Kota Sorong dengan persamaan regresi $\mathrm{Y}=39,396+0,543 \mathrm{X}$, dengan kriteria pengambilan keputusan berdasarkan hasil pengolahan data dengan menggunakan SPSS 23.0 bahwa hasil perhitungan nilai sig. adalah $0,000<0,005$ dan perbandingan nilai $t_{\text {hitung }} 5,372>t_{\text {tabel }} 2,045$.
\end{abstract}

Kata Kunci : Pengaruh, Cooperative Script (CS), Hasil Belajar.

\section{Pendahuluan}

Pendidikan merupakan salah satu

perwujudan dari kebudayaan manusia yang dinamis dan sarat perkembangan. perkembangan dalam bidang pendidikan dapat berupa perbaikan pendidikan pada semua tingkat. untuk antisipasi kepentingan masa depan, perbaikan dan inovasi perlu terus dilakukan. siswa dituntut untuk mampu mengikuti perkembangan dalam pendidikan tersebut sebagai bekal agar nantinya mereka bisa bersaing dalam dunia kerja. Agar hal tersebut dapat terwujud, maka perlu diadakannya upaya peningkatan mutu dalam proses belajar mengajar di kelas.

Upaya dalam peningkatan mutu pendidikan tidak terlepas dari kegiatan belajar mengajar dikelas. kerja sama antara guru dengan siswa merupakan hal yang sangat penting dalam kegiatan belajar 
mengajar di kelas. agar siswa mampu menyerap materi pelajaran maksimal dan optimal dibutuhkan umpan balik dari siswa. Oleh karena itu, selain memahami dan menguasai materi pelajaran guru dituntut untuk dapat memilih model serta metode pengajaran yang sesuai sehingga dapat mempengaruhi hasil belajar siswa.

Salah satu model pembelajaran yang membuat siswa ikut berperan aktif dalam proses belajar mengajar dikelas adalah model pembelajaran kooperatif. Banyak jenis model pembelajaran kooperatif yang telah berhasil meningkatkan hasil belajar siswa saat diterapkan dalam pembelajaran dikelas. (Setyo, 2017; \& Arsyad, RB, 2016).

Model pembelajaran kooperatif adalah model pembelajaran yang mengelompokkan siswa dalam proses belajar mengajar dikelas. Dalam kelompok kecil siswa cenderung lebih mudah diamati dan dikontrol oleh guru, siswa dapat berdiskusi dan saling menjelaskan untuk memahami dan menemukan jawaban dari tugas-tugas yang diberikan. sehingga proses pembelajaran dapat terlaksana maksimal dan setiap anggota dalam kelompok dapat memahami materi yang diberikan dengan baik. Hal ini sejalan dengan pendapat dari Trisnawati (2017) yang menyatakan bahwa Penggunaan model pembelajaran kooperatif akan mengarahkan siswa untuk aktif, baik dalam berdiskusi, tanya jawab, mencari jawaban, menjelaskan dan juga menyimak materi yang dijelaskan oleh teman.

Pembelajaran kooperatif memiliki banyak tipe. Tipe-tipe dari pembelajaran kooperatif dapat dipilih sesuai dengan jenis materi yang akan diberikan dan tujuan dari pembelajaran. Ada beberapa model pembelajaran kooperatif yang mengelompokkan siswanya secara berpasangan, sebagaimana penelitian tindakan kelas yang dilakukan Trisnawati (2016) yang berhasil meningkatkkan hasil belajar siswa setelah menerapka model pembelajaran kooperatif tipe Think-Pair-Share yang memasangkan siswa dalam kelas untuk melakukan pembejaran secara berpasangan.

Model pembelajaran berpasangan lainnya adalah model pembeajaran cooperative script. cooperative script yaitu suatu model pembelajaran yang dapat membuat siswa berpikir secara sistematis dan berkonsentrasi pada materi pelajaran serta siswa dilatih untuk bekerja sama, serta siswa dapat menemukan ide-ide pokok pembelajaran. Lambiotte, (2013). Cooperative script adalah model pembelajaran yang mengarahkan siswa bekerja berpasangan dalam memahami dan mengikhtisarkan materi yang dipelajari. 
Langkah-langkah perbelajaran cooperative script menuntuk siswa untuk menyelesaikan materi yang harus dipahami bersama dengan pasangan dan kemudian membuat kesimpulan dari pada yang telah mereka diskusikan. Kedua siswa dalam pasangan akan saling bergantian peran yaitu sebagai pembicara dan pendengar, hal ini mampu untuk membuat siswa sama-sama aktif dalam kelompok, sehingga pemahaman siswa dalam kelompok menjadi merata.

Beberapa penelitian yang telah dilakukan dalam menerapkan pembelajaran cooperative script yaitu oleh: Kusuma, J.W., \& Hamidah (2019) dengan Hasil penelitian menunjukkan model pembelajaran cooperative script berpengaruh positif terhadap hasil belajar dengan harga $F_{\text {hitung }}=$ 11,94 > $\mathrm{F}_{\text {tabel }}=4,02$ dengan tingkat signifikansi $\alpha=5 \%$; Fathurrahman, $\mathrm{M}$ (2016) dengan hasil penelitian pada siklus I memperoleh nilai rata-rata 55,34 dengan persentase ketuntasan belajar sebesar $58.6 \%$ meningkat pada siklus II menjadi nilai ratarata siswa 81.93 dengan persentase belajar sebesar 93.1\%; dan Tiara, Irma., Sanjaya., \& Edi (2014) Berdasarkan hasil penelitian, diketahui bahwa model cooperative script memiliki pengaruh yang signifikan positif terhadap hasil belajar dengan hasil uji t yaitu $\mathrm{t}_{\text {hitung }} 6,409=\geq \mathrm{t}_{\text {tabel }}=1,670$.

AdMathEdu | Vol.9 No.2| Desember 2019
Berdasarkan beberapa hasil penelitian tersebut, maka peneliti ingin mengetahui pengaruh pembelajaran cooperative script terhadap hasil belajar. Oleh karenanya penulis melaksanakan penelitian yang berjudul "pengaruh model pembelajaran cooperative script terhadap hasil belajar 'matematika siswa kelas IX SMP Negeri 1 Kota Sorong."

\section{Metode Penelitian}

Populasi dalam penelitian ini adalah seluruh siswa kelas IX SMP Negeri 1 Kota Sorong tahun pelajaran 2017/2018, dengan dua kelas sebagai sampel acak, sehingga dipilih kelas IX A yang diberikan model pembelajaran CS (Cooferative Script) sebagai kelas eksperimen dan kelas IX B yang diberikan model pembelajaran Biasa sebagai kelas kontrol. Penelitian ini merupakan eksperimen semu dengan desain pretest-posttest non-equivalent group design. Adapun teknik pengumpulan data dalam penelitian ini adalah dengan memberikan soal pretest untuk mengumpulkan data sebelum diberikan perlakuan. Selanjutnya melakukan penelitian dengan memberikan perlakuan dengan menerapkan cooperative script pada kelas eksperimen dan mengambil data keterlaksanaan sintaks pembelajaran cooperative script dan aktivitas siswa melalui 
observasi, serta pada akhir penelitian diberikan soal posttest untuk mengumpulkan data peningkatan hasil belajar setelah diberikan perlakuan pada masing-masing kelas.

Setelah diperoleh data pre test dan post test hasil belajar, kemudian data dianalisis untuk mengetahui skor gain dari kelas eksperimen maupun kelas kontrol. Dari hasil gain tersebut dilakukan uji normalitas dan uji homogenitas. Jika data berdistribusi normal dan homogen, maka analisis data dapat dilanjutkan ke tahap berikutnya yaitu uji regresi untuk mengetahui adanya pengaruh model pembelajaran Cooperative Script terhadap hasil belajar. Kemudian dari hasil uji regresi, dilakukan pengambilan keputusan hipotesis penelitian dengan 2 acuan, yaitu melalui nilai signifikansi dan dan perbandingan nilai $t_{\text {hitung }}$ terhadap $t_{\text {tabel. }}$.

\section{Hasil dan Pembahasan}

\section{Hasil Penelitian}

\footnotetext{
Setelah melakukan perlakuan terhadap kelas eksperimen dengan menerapkan model CS pada kelas IX A dan kelas IX B sebagai kelas kontrol, didapat beberapa data hasil penelitian sebagai berikut:
}

Dari proses pembelajaran yang telah dilakukan pada kelas eksperimen dan kelas kontrol selama 3 kali pertemuan, berikut data hasil observasi keterlaksanaan pembelajaran pada kedua kelas disajikan dalam Gambar 1.

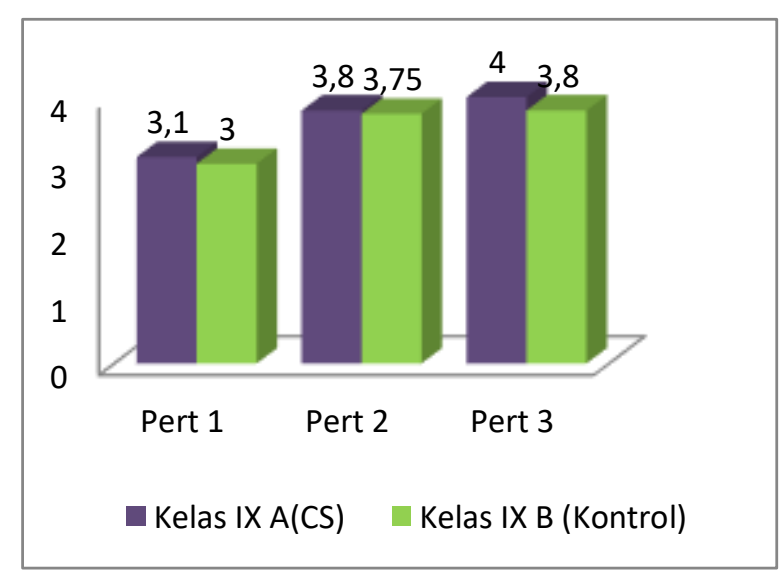

Gambar 1. Grafik Keterlaksanaan Pembelajaran

Data keterlaksaan pembelajaran pada gambar 1 terlihat bahwa kedua kelas berada pada kategori baik. Sehingga dapat diasumsikan bahwa pembelajaran berjalan sesuai dengan yang telah direncanakan dalam RPP. selain melakukan observasi terhadap keterlaksanaan pembelajaran, selama proses belajar berlangsung juga diobservasi keaktivan siswa di kelas saat pembelajaran, data hasil observasi keaktifan siswa dipaparkan pada gambar 2 berikut. 


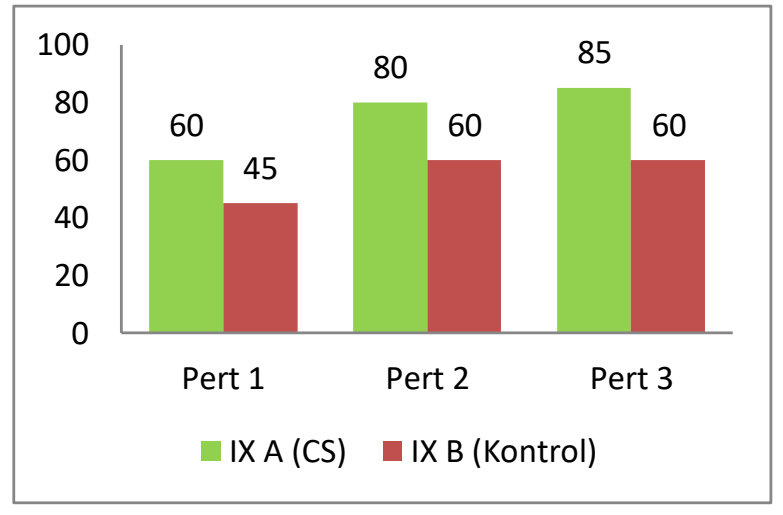

Gambar 2. Grafik Hasil Observasi Keaktifan

\section{Siswa}

Gambar 2 menunjukkan keaktifan siswa pada kelas eksperimen dan kelas kontrol. Dari gambar terlihat bahwa siswa lebih aktif dalam pembelajaran dengan menerapkan model Cooperative Script dikelas dibandingkan kelas kontrol. Pastisipasi dan umpan balik dari siswa yang baik menandakan adanya pemahaman yang baik dari siswa pada materi pembelajaran. Berikut data hasil pre test dan post test disajikan dalam tabel 1.

Tabel 1. Rata-Rata gain kelas eksperimen dan kelas kontrol

\begin{tabular}{cc}
\hline Kelas & Rata-rata Gain \\
\hline IX A (Eksperimen) & 0,7 \\
IX B (Kontrol) & 0,4 \\
\hline
\end{tabular}

Berdasarkan hasil analisis gain kedua kelas pada tabel 1, terlihat bahwa nilai gain kelas eksperimen 0,7 , ini menunjukkan bahwa perbedaan hasil belajar siswa dari sebelum perlakuan dan setelah perlakuan yaitu berada pada kategori sedang, sedangkan kelas eksperimen dengan nilai gain berada pada kategori rendah.

Sebelum melakukan uji hipotesis, dilakukan uji prasyarat pada data hasil penelitian, berikut uji Normalitas dan uji Homogenitas dari data hasil pemelitian di sajikan dalam tabel 2.

Tabel 2. Hasil Uji Normalitas

\begin{tabular}{ccc}
\hline Kelas & Asyim p.Sig. & Keterangan \\
\hline Eksperimen & 0,158 & Normal \\
Kontrol & 0,127 & Normal \\
\hline
\end{tabular}

Hasil uji normalitas menunjukkan signifikan dalam uji Shapiro wilk, untuk nilai n-gain pada kelas eksperimen dan kelas kontrol lebih dari 0,05 , berarti data berdistribusi normal. Berikutnya dilakukan uji homogenitas untuk data hasil penelitian yang disajikan dalam tabel 3.

Tabel 3. Hasil Uji Homogenitas

\begin{tabular}{ccc}
\hline Data & Signifikan & Keterangan \\
\hline Post Test & 0,289 & Homogen \\
\hline
\end{tabular}

Hasil uji homogenitas pada data post test yaitu varian kelompok post test dari kelas ekperimen dan kelas kontrol adalah sama atau homogen.

setelah dilakukan uji prasyarat, didapat hasil untuk data penelitian yaitu normal dan homogen, sehingga selanjutnya dapat dilakukan Pengujian Hipotesis dengan 
menggunakan Uji Regresi yang ditampilkan dalam tabel 4.

Tabel 4. Hasil Uji Regresi

\section{Coefficients $^{\text {a }}$}

Standardized

Unstandardized Coefficients Coefficients

\begin{tabular}{crrrrrr}
\hline \multicolumn{1}{l}{ Model } & \multicolumn{1}{c}{ B } & Std.Error & Beta & t & Sig. \\
\hline 1 & (Constant) & 39.396 & 6.495 & & 6.066 & 0.000 \\
& X & 0.543 & 0.101 & 0.712 & 5.372 & 0.000
\end{tabular}

Dari tabel 4 dapat diketahui bahwa persamaan regresi dari penelitian ini adalah $\mathrm{Y}=39,396+0,543 \mathrm{X}$. hal ini bermakna bahwa jika tidak diberikan perlakuan dengan model cooperative script, maka tingkat konsistensi hasil belajar siswa adalah 39,396, Dan setiap $1 \%$ perlakuan dengan model cooperative script (X) maka akan terjadi peningkatan hasil belajar sebesar 0,543.

Untuk pengujian hipotesis, Dasar pengambilan keputusan ada dua acuan sebagai berikut

\section{Berdasarkan nilai signifikansi (sig.)}

Berdasarkan output SPSS "coefficients" pada tabel 4, diketahui bahwa nilai sig. adalah 0,000, karena nilai $0,000<$ 0,005, maka dapat disimpulkan bahwa $\mathrm{H}_{0}$ ditolak dan $\mathrm{H}_{1}$ diterima. Ini berarti bahwa ada pengaruh dari penerapan Model cooperative script terhadap hasil belajar.

\section{Berdasarkan perbandingan nilai thitung dan tabel}

Berdasarkan output SPSS pada tabel 4 , diperoleh nilai $t_{\text {hitung }} 5,372>\mathrm{t}_{\text {tabel }} 2,045$.
Dari perbandingan nilai $t_{\text {hitung }}$ dan $t_{\text {tabel }}$ disimpulkan bahwa $\mathrm{H}_{0}$ ditolak dan $\mathrm{H}_{1}$ diterima. Ini berarti bahwa ada pengaruh dari penerapan Model cooperative script terhadap hasil belajar.

Berdasarkan nilai signifikansi dan uji t, maka dapat ditarik kesimpulan bahwa terdapat pengaruh positif yang signifikan dari penerapan model pembelajaran cooperative script terhadap hasil belajar Siswa kelas IX A SMP Negeri 1 Kota Sorong.

\section{Pembahasan}

Penelitian dilakukan pada dua kelas, kelas IX A sebagai kelas Eksperimen dengan memberikan perlakuan berupa penerapan Model Cooperative Script, dan Kelas IX B sebagai kelas Kontrol tanpa diberi perlakuan khusus (pembelajaran konvensional seperti biasa).

Hasil penelitian menunjukkan adanya pengaruh positif yang signifikan dari penerapan model Cooperative Script terhadap hasil belajar kelas IX A SMP Negeri 1 Kota Sorong dengan persamaan regresi $\mathrm{Y}=$ $39,396+0,543 \mathrm{X}$, dengan kriteria pengambilan keputusan berdasarkan hasil pengolahan data dengan menggunakan SPSS 23.0 bahwa hasil perhitungan nilai sig. adalah $0,000<0,005$ dan perbandingan nilai $\mathrm{t}_{\text {hitung }} 5,372>\mathrm{t}_{\text {tabel }} 2,045$. 
Hasil ini terjadi karena beberapa hal, yaitu berdasarkan hasil observasi keterlaksanaan pembelajaran berada pada kategori baik dari pertemuan pertama sampai pertemuan ketiga, hal ini menunjukkan bahwa sintaks pelaksanaan pembelajaran dari model Cooperative Script telah terlaksana sesuai dengan yang direncanakan dalam RPP.

Terlaksananya dengan baik sintaks pembelajaran membuat proses dan tujuan yang diharapkan dari penerapan model tersebut tercapai, yaitu pemahaman yang baik oleh semua siswa dari proses meringkas dan membacakan ringkasan serta menanggapi ringkasan pasangan dalam kelompoknya. Hal ini yang mengakibatkan seluruh siswa berperan aktif dalam pembelajara, sehingga tercapainya pemahaman materi yang menyeluruh pada semua siswa dapat terealisasi.

Keaktifan siswa dalam kelas juga diobservasi selama proses pembelajaran dengan model Cooperative Script, dalam proses pelaksanaannya terlihat siswa yang antusias dalam mengikuti langkah-langkah pelaksanaan model CS, hal ini terlihat dari hasil observasi keaktifan siswa pada hari ketiga mencapai $85 \%$.

Pembelajaran pembelajaran dengan model cooperative script diawali dengan kerja perorangan (individu), masing-masing siswa mempelajari dan meringkas materi pelajarannya, kemudian secara berpasangan mendiskusikan hasil dari proses meringkas. Salah satu siswa bertugas sebagai pembaca ringkasan dan siswa yang lain sebagai pendengar serta mengoreksi dan melengkaspi jika terdapat kekurangan atau kesalahan- kesalahan dan guru membimbing serta mengamati kegiatan siswa. Berikutnya siswa bertukar peran, siswa yang awalnya sebagai pembicara ditukar menjadi pendengar, dan sebaliknya kemudian guru membantu siswa menyusun kesimpulan. Langkah-langkah pembelajaran terseut memiliki makna dan manfaat pada diri siswa dalam pembelajaran.

Siswa menjadi aktif dalam kelompok karena kelompok hanya terdiri dari dua siswa, sehingga semua siswa memiliki peran yaitu siswa berperan sebagai pembicara dan pendengar. Siswa juga dilatih untuk mengungkapkan pendapatnya dengan lebih teliti dalam mengoreksi hasil ringkasan teman kelompok yang sedang berperan sebagai pembicara. Hal ini sejalan dengan (tiara Irma) siswa menjadi lebih aktif karena jumlah anggota kelompok yang hanya 2 orang dan masing- masing siswa memiliki peran. 
Keaktifan siswa pada perannya dalam kelompok mendorong siswa untuk menjadi lebih kreatif dan percaya diri, dan membuat siswa menjadi lebih mengingat materi pembelajaran karena mengalami pengulangan beberapa kali dalam proses meringkas materi dan menyampaikan materi (sebagai pembicara) dan mendengarkan serta mengungkapkan pendapat (sebagaipendengar). Hal ini sesuai dengan AdMathEdu | Vol.9 No.2| Desember 2019 I AdMathEdu | Vol.9 No.2| Desember 2019 pembelajaran yang mampu menıngkatkan kemampuan siswa dalam mengingat adalah pembelajaran dengan model cooperative script.

Pembelajaran Cooperative Script juga membuat siswa banyak mengungkap ide-ide baru dalam menemukan cara penyelesaian soal, dengan perbedaan kemampuan yang dimiliki siswa, membuat beberapa siswa menyelesaikan dan memahami penyelesaian soal dengan cara yang berbeda-beda. Hal ini juga diungkapkan oleh Lamusu dkk (2013: 3) model pembelajaran cooperative script akan menimbulkan ide- ide pokok atau gagasan baru dari siswa itu sendiri. Setra ungkapan dari Susiloyoga, (2016) yaitu model pembelajaran cooperative script cocok digunakan untuk meningkatkan ide-ide baru khususnya dalam memecahkan suatu permasalahan serta kenumbuhkan keberanian dalam menyampaikan hal-hal baru yang diyakininya benar

Berdasarkan hal tersebut, maka dapat disimpulkan bahwa proses pembelajaran dengan model Cooperative Script dengan kegiatan-kegiatan dalam model ini seperti membaca materi, menulis ringkasan materi, membacakan hasil ringkasan kepada $\begin{aligned} & \text { Pengarug... (Nika) } \\ & \text { Pengarug... (Nika) }\end{aligned}$ membuat siswa menjadı lebıh mudah dalam mengingat dan memahami materi siswa menjadi lebih aktif dan memungkinkan menemukan ide-ede baru sehingga membuat proses pembelajaran berjalan maksimal dan hasil belajar yang didapat bisa meningkat.

Peningkatan tersebut terlihat dari analisis nilai rata-rata gain hasil belajar siswa yaitu berada pada kategori sedang dengan skor gain 0,7 .

Selain sejalan dengan kajian teori, hasil uji hipotesis penelitian ini pun sejalan dengan penelitian yang dilakukan oleh beberapa peneliti diantaranya penelitian jenis eksperimen oleh Kusuma, J.W., \& Hamidah (2019) dengan Hasil penelitian menunjukkan model pembelajaran cooperative script berpengaruh positif 
terhadap hasil belajar dengan harga $\mathrm{F}_{\text {hitung }}=$ 11,94 $>\mathrm{F}_{\text {tabel }}=4,02$ dengan tingkat signifikansi $\alpha=5 \%$; dan Tiara, Irma., Sanjaya., \& Edi (2014) Berdasarkan hasil penelitian, diketahui bahwa model cooperative script memiliki pengaruh yang signifikan positif terhadap hasil belajar dengan hasil uji t yaitu $t_{\text {hitung }} 6,409=\geq t_{\text {tabel }}$ $=1,670$.

Penelitian jenis PTK yang dilakukan Sari, Yuliana Puspita., dkk (2018) pada kelas VIII.6 SMP Negeri 1 Kota Bengkulu tahun ajaran 2016/2017 yang berjumlah 31 orang. Dengan Hasil penelitian ini menunjukkan bahwa penerapan model kooperatif tipe cooperative script dapat meningkatkan hasil belajar matematika siswa yaitu dengan rata-rata nilai 69 menjadi 86,9 dengan persentase ketuntasan belajar klasikal dari 28,13\%, menjadi 87,09\%.; Hasbinet (2017) dengan hasil penelitian rata-rata nilai siswa yang pada awal siklus hanya 58,33 dan pada Siklus II yakni 80.00 dengan persentase peningkatan sebesar 10\%; dan Fathurrahman, M (2016) dengan hasil penelitian pada siklus I memperoleh nilai rata-rata 55,34 dengan persentase ketuntasan belajar sebesar $58.6 \%$ meningkat pada siklus II menjadi nilai rata-rata siswa 81.93 dengan persentase belajar sebesar $93.1 \%$.
Secara keseluruhan dari hasil penelitian dan dari pembahasan berdasarkan kajian teori dan hasil uji hipotesis, maka dapat disimpulkan bahwa Hasil penelitian berpengaruh positif yang signifikan dari penerapan model Cooperative Script terhadap hasil belajar kelas IX A SMP Negeri 1 Kota Sorong

\section{Kesimpulan}

Berdasarkan hasil penelitian dan pembahasan tersebut, maka dapat disimpulkan bahwa terdapat pengaruh yang positif secara signifikan pada penerapan model CS terhadap hasil belajar siswa kelas IX A SMP Negeri 1 Kota Sorong.

Selanjutnya penelitian ini masih dapat dikembangkan lebih lanjut dengan menambahkan variable lain dalam penelitian serta pembelajaran di kelas.

\section{Pustaka}

Arsyad, RB. (2016). Meningkatkan Hasil Belajar Matematika dengan Menggunakan Model Cooperative Learning dan teknik Napier pada siswa kelas IV B SD Muhammadiyah 2 Kota Sorong. Qalam: Jurnal Ilmu Kependidikan, Vol. 5, No. 2, Hal 1425, Desember 2016.

Fathurrahman, M. (2016). Meningkatkan Hasil Belajar Matematika Melalui Model Pembelajaran Cooperative Script Pada Siswa Sekolah Menengah 
Atas. Qalam: Jurnal Ilmu Kependidikan, Vol. 5, No. 1, Hal 1-7, Juni 2016

Hasbinet. (2017). Penerapan Metode Cooperative Script Dalam Meningkatkan Hasil Belajar Siswa Kelas IV SD Pada Mata Pelajaran Matematika. Jurnal Ilmu Pendidikan Sosial, Sains, dan Humaniora, Vol. 3, No. 3, September 2017.

Kusuma, J.W., \& Hamidah. (2019). Pengaruh Model Pembelajaran ARIAS dan Cooperative Script terhadap minat dan hasil belajar Matematika. ANARGYA: Jurnal Ilmiah Pendidikan Matematika, Vol. 2, No. 1, April 2019.

Lambiotte, 2013.-Model-Model Pengajaran dan Pembelajaran.Yogyakarta: Pustaka Pelajar.

Lamusu, H Mitrawati, dkk. 2013. Penerapan Model Pembelajaran Cooperative Script untuk Meningkatkan Hasil Belajar Hidrolisis Garam Siswa Kelas XI IPA2 SMA Negeri 1 Tapa Kabupaten Bone Bolango Provinsi Gorontalo. Jurnal Universitas Negeri Gorontalo 1(1).

Sari, Yuliana Puspita., Rusdi., Effie Efrida Muchlis. (2018). Upaya Meningkatkan Hasil Belajar Siswa Dengan Penerapan Model Pembelajaran Cooperative Script Pada Materi Lingkaran. Jurnal Penelitian Pembelajaran Matematika Sekolah (JP2MS), Vol.2, No.1, April 2018.

Setyo, Arie Anang. (2017). Keefektifan Pembelajaran Kooperatif Tipe STAD
Integrasi Teori Belajar Van Hiele Pada Materi Geometri di Kelas V Sekolah Dasar. Qalam: Jurnal Ilmu Kependidikan, Vol. 6, No. 1, Hal. 111, Juni 2017

Slavin, R.E., 2006. Accommodating student diversity in reading and writing instruction: a cooperative learning approach, Journal of Technology Education, 18 (1): 52-55

Susiloyoga, J. 2016. Upaya Meningkatkan Kemampuan Menentukan Peluang Suatu Kejadian dengan Model Pembelajaran Kooperative Script pada Siswa Kelas IXIPA 3 SMA Negeri 2 Madiun. Jurnal Ilmiah Edukasi Matematika, 39-62.

Tiara, Irma., Sanjaya., \& Edi, R. (2014). Pengaruh Penerapan Model Cooperative Script Terhadap Hasil Belajar Kimia Siswa Kelas X SMA Negeri 3 Tanjung Raja. Jurpenkim, Volume 1, Nomor 2.

Trisnawati, Nika Fetria. (2016). Meningkatkan Hasil Belajar Matematika Siswa dengan menggunakan Model Pembelajaran Kooperatif Tipe Think-Pair-Share (TPS) pada Siswa Kelas VB SD Muhammadiyah I Kota Sorong. Qalam: Jurnal Ilmu Kependidikan, Vol. 5, No. 2, Hal 26-32, Desember 2016.

Trisnawati, Nika Fetria. (2017). Efektivitas Model Pembelajaran Kooperatif Tipe Two Stay Two Stray dengan Pendekatan Saintifik dalam Pembelajaran Matematika pada Siswa SMP Negeri 2 Kota Sorong. 
Jurnal Median, Vol. IX, No. 3, Hal. 36-42, Oktober 2017. 
